Selçuk University, imranaslan@selcuk.edu.tr, Konya-Turkey

http://dx.doi.org/10.12739/NWSA.2014.9.4.4C0188

\title{
POINTS OF VIEW BY FOREIGNERS LIVING IN KONYA TO TURKISH BRANDS
}

\section{ABSTRACT}

Brands are composed of figures, signs or symbols such as logos, colours and designs to be formed for service or products to be different from their counterparts. However, brands have nowadays a large meaning that defines its classical description. It has an understanding that pioneers novelties by forming the perception of quality, being emotional constituents and leading to links to their consumers. While entering different brandets all over the world, Turkish brands are encountering a new type of consumers in Turkey migrating from different countries. Most of these new consumers meet Turkish brands for the first time. The present study was performed to investigate the perception of Turkish brands living in Konya. How these consumers look at the brands of clothes, food, beverages, GSM operators and whiteware appliances, and perceive these brands are tried to be determined. Which brands they chose according to their preferences, and the awareness of Turkish brands were evaluated in the study.

Keywords: Brand, Awareness of Brands, Image of Brands, Consumer, Turkish Brand

\section{KONYA'DA YAŞAYAN YABANCILARIN TÜRK MARKALARINA BAKIŞLARI}

\section{ÖZET}

Marka, ürün ya da hizmetlerin rakiplerinden farklılaşması için oluşturulan logo, renk, tasarım gibi şekil, isim, işaret veya sembollerin birleşmesinden oluşmaktadır. Günümüzde ise marka bundan çok daha fazlasını ifade etmektedir. Marka, kalite algısı oluşturan, duygusal bileşenleri olan, tüketicisiyle bağ kuran, yeniliklere öncülük eden bir anlayışa sahiptir. Türk markaları Dünya'daki farklı pazarlara girmeye çalışırken, ülke içinde ise farklı yerlerden göç eden yeni bir tüketiciyle tanışmaktadır. Bu tüketicilerin büyük bir kısmı Türk markalarıyla ilk defa karşılaşmaktadır. Bu çalışma Konya'da yaşayan yabancıların Türk marka algılarını ölçmek için yapılmıştır. Bu yabancı tüketicilerin, giyim, yiyecek, içecek, gsm ve beyaz eşya markalarına bakışları ve marka algıları belirlenmektedir. Kendi kültür ve yaşam tarzlarına göre hangi markaları tercih ettikleri, Türk marka bilinirliği incelenmiştir.

Anahtar Kelimeler: Marka, Marka Farkındalığı, Marka İmajı, Tüketici, Türk Markaları 


\section{INTRODUCTION (GÍRİŞ)}

Consumers live in a world of brands. A consumer has to choose one brand among hundreds of those different from each other while making any decision on a product. These preferences are determined in accordance with various criteria. Features such as past experiences of consumers, advertisements, campaigns, prices, etc. come to the front in choosing a brand.

Firms want their own brands to be recalled while consumers are purchasing and a loyalty to be created to their brands. In order to achieve this aim, they have to provide the awareness of their brands at first. The awareness of a brand is that consumers are able to distinguish the brand against others, based on its formal and contextual characteristics since previously seeing or hearing about the brand (Tosun, 2010:111). Increasing the awareness of a brand newly launched into brandet is one of the first objectives. Then, the firm expects to be recalled in purchases or to be the brand firstly coming into mind. Therefore, the awareness of a brand seems to be the first step of these procedures.

Brand image is also of the same importance in consumers' purchases as the awareness of a brand. Brand image is composed of the total of impressions consumers have formed about the brand in their brain so far. Consumers put the messages of communication efforts the brand has performed or their experiences on these accumulations. So, they create the brand image in a positive or negative direction. Purchases are directly affected by which direction the image is developed. But, for an image to be formed first, brand awareness must be provided.

\section{RESEARCH SIGNIFICANCE (ÇALIŞMANIN ÖNEMİ)}

A field research was performed in order to evaluate the Turkish brand recognition of foreign people living in Konya. In the selection of sampling, a purposeful sampling was given. In this research, the aim was to measure the Turkish brand perception and the brand recognition, that's why, Turkish citizens were excluded from the sampling. Face to face questionnaire was applied to the participants of the study, and 110 questionnaire forms were considered to be appropriate for the analysis after the pre-study.

\section{SUBJECT (ANAKONU)}

\subsection{Conception of Brand (Marka Kavramı)}

A brand is the total of emotions and opinions a consumer owns about a product, as well as physical characteristics such as only logos or names (Aktuglu, 2004:12). A brand is also a distinctive name or symbol describing a group or a producer's goods or services and distinguishing these against the products of other producers. Furthermore, while a brand lets a consumer rely on showing the source of the product, it protects itself from similar or fake brands, as well (Aaker, 1991:198).

Brand is a pledge and guarantee of quality given by the producer. Brand provides distinguishability, preferability and a strong image of the product (Perry and Wisnom, 2003:12). Each brand gives a promise to its consumers in accordance with its characteristics. One of the characteristics making a brand as a special one is the power of being able to stand behind its promises. Today, it is not enough for a brand to be different from hundreds of competitors with names, logos or physical characteristics. Brands must give reasons for consumers to make any preference, and these reasons can be rational or emotional. The consumer will make a preference via the rational or emotional link s/he has formed or by the advantage 
given to her or him through the pledge. Of course, although a single purchase of a product is insufficient for a customer to become a regular customer, loyalty to that product or brand must be provided. There are some advantages a brand provides for consumers (Bylthe, 2001:141):

- Brands give a true sense of security. Consumers with a certain budget want to take no risks buying products produced by unknown brands.

- Products of trustworthy brands are perceived to have more quality and chosen by consumers rather than products without brands.

- Brands make consumers be aware of their products, and so accelerating the selection of their products during purchasing.

- Brands give information to consumers about products. The brands previously used by consumers affect the attitutes and beliefs of consumers during the next purchasings.

- Products with brands mean a sort of guarantee for consumers and protect consumers.

Brands are not a simple result of advertisements made by firms. A brand is what a consumer perceives in his or her mind. The consumers' mind is under the bombardment of thousands of messages by mass media instruments every day. Not only must brands follow daily the impressions they have formed, but also constitute a distinctive place in consumers' mind to be a real brand. The less privileged and the more different a brand is in consumers' mind, the more the brandet share captured by competitors increases. The more privileged a brand becomes in consumers' mind, the more it becomes close to the description of "real brand" (Knapp, 2000:7).

While buying any product, consumers decide sometimes by looking at all characteristics of a product in general, sometimes at only one characteristic of the product. Consumers evaluate the prices, packages, colours, quality, and delivery, conditions of credit and guarantee, post-sale services, style and design features of a product. Consumers also want to choose a brand due to both these characteristics and values or processes developing because of sociological, psychological and economic effects. They may have such different aims at choosing a brand as being a natural member of a social group, being liked, forming a distinguished name in society and having a different image (Ar, 2007:5). Not only do brands offer choices to consumers about the fundamentals of a product, but they make consumers get satisfaction psychologically or socially, as well. When unwrapping the packages of products physically similar to each other, it often seems that no distinctions can be made as to the name of that brand. Hereby, it can be understood that brands add value to the products and increase their preferability. Consumers who are the carriers of a high-value brand such as clothing or an automative benefit those brands when intending to show themselves as a member of high status groups. Today, brands are prepared in a way to reflect consumers' personalities and images rather than meeting consumer needs.

\subsection{Image of Brands (Marka Imajı)}

Images concerning brands are related with how consumers perceive those brands. Brands are placed into a consumer's mind via communication efforts. But each consumer creates an image in the mind by making different comments on the same message and correlating them with past experiences (Hung, 2005:239). Brands represent the firms and products they belong to and reflect certain images of the brand 
(Aktuglu, 2004:12). Brands show what customers perceive and feel about a product and its performance. The value of a strong brand indicates the strength of catching customers' preference and loyalty (Kotler and Armstrong, 2004:291). Apart from describing and representing a certain product, a brand is not merely composed of a name, but includes different meanings. A brand is a sign of opinions of customers about a product (Odabasi and Oyman, 2004:369). Image of brands is among factors directly affecting the purchasing habits of consumers. Images of brands which affected customers positively in the past will be positive in present situation, as well and lead to positive effects on a consumers' decision process although conflicting assertions are present. The fundementals of brand images are the total of impressions that past experiences have created in consumers' minds (Elden, 2009:116).

Image of brands is a whole of impressions and opinions a product leaves on target groups. For many companies, the risk for entering in a new brandet or introducing a new product is quite excessive. One of the ways to reduce the risk is to provide recognition and prestige or to use the image of the brand as a power chosen to increase the reliability and unobserved characteristics of that brand. With the image, products and/or services are given at appropriate prices and quality to meet consumer needs, and the risk for purchasing the products unconsciously is reduced (Tuna and Tuna, 2007:125). Brand image affects the first purchase of a product, as well as influencing whether the consumer will buy the product which s/he has bought once before; in other words, whether one will become a continuous or regular customer (Mucuk, 1997:128).

\subsection{Awareness of Brands (Marka Farkındalığı)}

Brand awareness is related with being informed about brands and distinguishing brands and involves brand recognition and remembrance. So, brands become strong as leading ones in purchases and preferences. Brand recognition is directly associated with the design, package, logos or symbols of the products (Uztug, 2002:30). This can be added brand name, personality characteristics or slogans. Consumers must be aware of brands to make any product purchase which is one of the greatest objectives of brands. But brand awareness affects not only the purchase of a product but also the image of it. Consumers will have positive or negative opinions about the brands they are aware of or not. Brand awareness is that brands become well-known, that they have a place in consumers' mind as well as competitors. Brand awareness is related with how successful they carry out functions such as signs, logos, words, etc. defined as brand identities. Brand awareness includes brand recognition and brand remembrance (Pira, Kocabaş and Yeniçeri, 2005:88).

Consumers generally prefer brands they consider while buying (Keller, 1993:50). Preferability of a firm which cannot create brand awareness, becomes low. Brand awareness will also bring a possible, positive brand image and brand loyalty. For this reason, brand awareness is very significant for realizing purchases and keeping on purchases. The benefits which brand awareness will provide, are as follows (Aaker, 1995:208):

- Brand awareness ensures that customers feel close to the brand, and people prefer brands they know, feel close to themselves.

- High brand awareness shows a power of unity and dependency between customers and enterprises.

- It helps products to be kept in mind within the process of purchasing. 
Awareness is associated with the intensity and power of the place a brand has in consumers' mind. Remembrance or recognition degree in consumers' mind refers to awareness degree of a brand (Tek, 1997:358). When brands present a simple definition and remembrance without benefiting from strong associations, they become effective in making decisions for purchases relating to brands. Awareness is very important for having more information and paying more attention to low involvement products in consumers. Because consumers show tendency to buy brands they only know and casually recall while buying low involvement products as products rapidly consumed. So the aim is to buy a known brand without making more efforts. This comes true with brand awareness (Babur Tosun, 2010:113).

\section{FINDINGS AND DISCUSSIONS (BULGULAR VE TARTIŞMALAR)}

\subsection{Procedure and Sample (Araştırmanın Uygulanması ve Örneklem)}

To estimate the participants' Turkish brand perceptions and brand recognition levels, the questions from three parts were asked. In the first part, following the scale of 9 articles prepared with the 5 point likert scale, the answers were taken as (1) Strongly Disagree, (2) Disagree, (3) Neutral, (4) Agree, (5) Strongly Agree. The questions were asked about the Turkish brand recognition in the second part of the questionnaire form and the participants' socio-demographic characteristics in the third part of the questionnaire. To determine the reliability of the scale, the coefficient of Cronbach's Alpha was calculated as .685.

The questionnaires were carried out in Konya in May 2014. The questions were asked to the participants in Arabic. The data were processed in an electronical environment using the SPSS 17.0 statistical program. To measure the perceptions and awareness of brands, the frequency analysis was performed. Also, the arithmetic average was estimated.

As a result of the literature study, the answers of these questions were investigated:

- Research Question 1: What are the reasons for preferring the Turkish brands by the participants?

- Research Question 2: Which ones of the Turkish product groups do the participants consume at most?

- Research Question 3: What is the Turkish brand perception of the participants?

- Research Question 4: Which ones of the basic need product brands do the participants have information about?

\subsection{Features of Participants (Katılımcıların Özellikleri)}

of all participants between the ages of $13-65,42.5 \%$ were women, and 49.2\% were men. Distribution of participants according to nationalities was as follows: Iraqians, 40.8\%; Palestinians, 26.7\%; Syrians, 10.8\%; and others, including Iranians, Afghanis and Yemenites; $1.7 \%$. As to educational status of all participants, 29.2\% were graduated from high schools, 27.5\% from secondary schools, 25.8\% from colleges, and 7.5\% from primary schools. Regarding professions, 48.3\% were unemployed, 22.5\% were housewives, 5\% were students, and 3.3\% were workers. As to economical status, 83.3 percent of participants were earning less than 475 US dollars/month, 2.5\% between 475-1425 US dollars/month, and 1.7\% above 2375 US dollars/month (1000 $\mathrm{TL}=$ nearly 475 US dollars). Upon investigating the duration of staying, $40.8 \%$ reported to be staying in Turkey between 6-12 months, 18.3\% between 13-24 months, 14.2\% less than 6 months, and 5.8\% more than two years. 
Table 1. Groups of products purchased

(Tablo 1. Ürün grubu satın alma)

\begin{tabular}{|l|r|r|}
\hline Explanation & Number & Percent \\
\hline Food & 107 & 62,9 \\
\hline Cleansing-Personal care & 37 & 21,8 \\
\hline Clothing & 16 & 9,4 \\
\hline White appliances & 9 & 5,3 \\
\hline Technology & 1 &, 6 \\
\hline Total & 170 & 100 \\
\hline
\end{tabular}

In Table 1, the distribution rates of groups of products purchased by the participants is seen. According to the findings, "food", "cleansing-personal products" and "clothing" are the mostly purchased groups with 62.9, 21.8 and 9.4\%, respectively. So, the participants were detected to spend only for basic needs and not to spend for luxurious consumer products.

Table 2. Brand selection criteria

(Tablo 2. Ürün seçiminde dikkat edilen özellik)

\begin{tabular}{|l|r|r|}
\hline Explanation & Number & Percent \\
\hline Price & 95 & 66,4 \\
\hline Quality & 41 & 28,7 \\
\hline Brand & 7 & 4,9 \\
\hline Missing & 10 & 8,3 \\
\hline Total & 143 & 100 \\
\hline
\end{tabular}

The features that the participants seek while purchasing products are seen in Table 2. According to these findings, "price", "quality" and "brand" are the most frequently sought factors with 66.4, 28.7 and 4.9\%, respectively. Perception of "brand" is far less than "price" as a factor affecting the choice, and the participants reported to care about "price" at most in purchasing a product. The prices of products are important for the participants because their levels of income are lower.

Table 3. Reasons for choosing Turkish brands

(Tablo 3. Türk markalarının tercih edilme sebebi)

\begin{tabular}{|l|r|r|}
\hline Explanation & Number & Percent \\
\hline Prepared according to Islamic rules & 100 & 36,5 \\
\hline Appropriate price & 67 & 24,5 \\
\hline Giving importance to hygiene & 60 & 21,9 \\
\hline Turkish brands of high quality & 24 & 8,8 \\
\hline Following fashion in clothing & 15 & 5,5 \\
\hline Durability of products & 8 & 2,9 \\
\hline Total & 274 & 100 \\
\hline
\end{tabular}

The reasons why refugees living in Turkey choose Turkish brand are presented in Table 3. "Preparation of these products according to Islamic rules" ranks first with 36.5\%, "appropriate pricing of products" is the second with 24.5\%; and, "giving importance to hygiene" is seen as the third factor with the rate of $21.9 \%$. Because all participants are muslims, "preparation of especially food products according to Islamic rules" is an important factor. However, another important point is that the participants take price into account due to staying in Turkey. 
Table 4. Preferred Turkish brands to foreign brands

(Tablo 4. Türk markalarının yabancı markaya tercihi)

\begin{tabular}{|l|r|r|}
\hline Explanation & Number & Percent \\
\hline Agree & 58 & 48,3 \\
\hline Certainly agree & 34 & 28,5 \\
\hline Don't know & 15 & 12,5 \\
\hline Don't agree & 3 & 2,5 \\
\hline Total & 110 & 100 \\
\hline
\end{tabular}

In Table 4, the distribution rates of choice of Turkish brands to foreign brands are seen. The responses to the question about whether the participants choose Turkish brands or not were as follows: "agree", 48.3; "certainly agree", 28.5\%; and, "don't know", 12.5\%. As a result, the participants are seen to choose Turkish brands instead of foreign ones.

Table 5. Rates of preferred Turkish brands according to product groups

(Tablo 5. Türk markalarının ürün gruplarına göre tercih edilirliği)

\begin{tabular}{|l|r|r|}
\hline Explanation & Number & Percent \\
\hline Food & 90 & 47,6 \\
\hline Clothing & 31 & 16,4 \\
\hline White appliances & 21 & 11,1 \\
\hline Cleansing & 17 & 9,0 \\
\hline Furniture & 14 & 7,4 \\
\hline Beverages & 12 & 6,3 \\
\hline Technology & 3 & 1,6 \\
\hline Home decoration & 1 &, 5 \\
\hline Total & 189 & 100 \\
\hline
\end{tabular}

When looking at which Turkish brands were chosen in product groups, "food", "clothing" and "white appliances" rank the first three items with $47.6,16.4$ and $11.1 \%$, respectively. The participants also reported to choose Turkish brands at a higher rate as both daily and durable consumer products, compared to foreign ones.

Table 6. Perception of quality of Turkish brands (Tablo 6. Türk marka kalite algısı)

\begin{tabular}{|l|r|r|}
\hline Explanation & Number & Percent \\
\hline Certainly agree & 53 & 44,2 \\
\hline Agree & 53 & 44,2 \\
\hline Don't know & 2 & 1,7 \\
\hline Don't agree & 2 & 1,7 \\
\hline Total & 110 & 100 \\
\hline
\end{tabular}

In Table 6, the distribution rates of perception of quality of Turkish brands are seen. Of all participants, 44.2\% responded as "certainly agree", and another 44.2\% preferred the item of "agree". The perception of Turkish brands was seen to be higher among the participants to a great extent.

In Table 7, whether the participants trust in Turkish brands or not can be seen. So, the participants responded as "agree" with 45\%, and "certainly agree" with $44.2 \%$. It is seen that the participants trust in Turkish brands on a large scale. 
Table 7. Trust in Turkish brands

(Tablo 7. Türk markalarına güven)

\begin{tabular}{|l|r|r|}
\hline & Number & Percent \\
\hline Agree & 54 & 45 \\
\hline Certainly agree & 53 & 44,2 \\
\hline Don't know & 2 & 1,7 \\
\hline Don't agree & 1 &, 8 \\
\hline Total & 110 & 100 \\
\hline
\end{tabular}

Table 8. Sympathy for Turkish brands (Tablo 8. Türk marka sevgisi)

\begin{tabular}{|l|r|r|}
\hline & Number & Percent \\
\hline Agree & 65 & 54,2 \\
\hline Certainly agree & 43 & 35,8 \\
\hline Don't know & 1 &, 8 \\
\hline Don't agree & 1 &, 8 \\
\hline Total & 110 & 100 \\
\hline
\end{tabular}

Whether the participants have sympathy for Turkish brands are shown in Table 8. According to the findings in this table, the responses by the participants to the question were as follows: "agree", 54.2\%; and "certainly agree", 35.8\%. Thus, the participants are seen to have sympathy for Turkish brands. The fact that the participants are familiar with Turkish culture and also supported economically while staying as refugees in Turkey has caused them to feel sympathy to Turkey and Turkish brands.

Table 9. Awareness of food brands in Turkey (Tablo 9. Türkiye'de gıda marka bilinirliği)

\begin{tabular}{|l|r|r|}
\hline Explanation & Number & Percent \\
\hline Ülker & 78 & 30,6 \\
\hline Sütaş & 36 & 14,1 \\
\hline Pınar & 25 & 9,8 \\
\hline Tat & 18 & 7,1 \\
\hline Tamek & 17 & 6,7 \\
\hline Torku & 12 & 4,7 \\
\hline Eti & 11 & 4,3 \\
\hline Eiliz & 9 & 3,5 \\
\hline Sek & 8 & 3,1 \\
\hline Kent & 7 & 2,7 \\
\hline Kemal Kükrer & 7 & 2,7 \\
\hline Mis & 6 & 2,4 \\
\hline Sarelle & 6 & 2,4 \\
\hline Ekici & 5 & 2 \\
\hline Piyale & 4 & 1,6 \\
\hline Komili & 3 & 1,2 \\
\hline Çaykur & 2 &, 8 \\
\hline Maret & 1 &, 4 \\
\hline Total & 255 & 100 \\
\hline
\end{tabular}

The rates of awareness of food brands in Turkey are presented in Table 9. According to the rates, Ülker, Sütaş and Pınar rank the first three brands with 30.6, 14.1 and 9.8\%, respectively. These brands are the most popular ones in food industry in Turkey with the highest brandet share although some are unpopular globally. 
Table 10. Awareness of furniture and home decoration brands (Tablo 10. Mobilya ve ev dekorasyon marka bilinirliği)

\begin{tabular}{|l|r|r|}
\hline Explanation & Number & Percent \\
\hline İstikbal & 68 & 30,5 \\
\hline Bellona & 28 & 12,6 \\
\hline Çilek & 24 & 10,8 \\
\hline Mondi & 18 & 8,1 \\
\hline Rapsodi & 16 & 7,2 \\
\hline Doğtaş & 15 & 6,7 \\
\hline Alfemo & 15 & 6,7 \\
\hline Kelebek & 14 & 6,3 \\
\hline Taç & 12 & 5,4 \\
\hline Kilim & 11 & 4,9 \\
\hline Yataş & 2 &, 9 \\
\hline Total & 223 & 100 \\
\hline
\end{tabular}

The findings obtained via the questions asked to measure the rate of awareness on Turkish furniture and home decoration brands are seen in Table 10. According to the results, İstikbal with 30.5\%, Bellona with $12.6 \%$ and Çilek with $10.8 \%$ are among the most known brands in furniture and home decoration industry in their opinion. These brands are the leaders of companies producing furniture and home decoration materials, and give advertisements to mass media instruments, especially to TVs. So, they have contributed to the formation of awareness related to their brands.

Table 11. Use of GSM operators

(Tablo 11. GSM operatör kullanımı)

\begin{tabular}{|l|r|r|}
\hline Explanation & Number & Percent \\
\hline Turkcell & 61 & 50,8 \\
\hline Avea & 42 & 35 \\
\hline Vodafone & 1 &, 8 \\
\hline Missing & 16 & 13,3 \\
\hline Total & 104 & 100 \\
\hline
\end{tabular}

In Table 11, which GSM operator is used by the participants is seen. According to this, Turkcell, Avea and Vodafone are among the first three operators with these rates: $50.8 \%, 35 \%$, and $0,8 \%$, respectively. Also, Turkcell has been chosen by the participants due to being the leading operator in the brandet and the advantages it obtained. 
Table 12. Awareness of clothing brands (Tablo 12. Giyim marka bilinirliği)

\begin{tabular}{|l|r|r|}
\hline Explanation & Number & Percent \\
\hline Koton & 64 & 25,6 \\
\hline Mavi & 35 & 14 \\
\hline Journey & 16 & 6,4 \\
\hline Bambi & 15 & 6 \\
\hline Mudo & 13 & 5,2 \\
\hline Rodi & 12 & 4,8 \\
\hline Desa & 12 & 4,8 \\
\hline Hotiç & 11 & 4,4 \\
\hline Sarar & 11 & 4,4 \\
\hline Colins & 10 & 4 \\
\hline Tergan & 7 & 2,8 \\
\hline İekyol & 5 & 2 \\
\hline Fabrika & 5 & 2 \\
\hline Vakko & 4 & 1,6 \\
\hline Karaca & 3 & 1,2 \\
\hline İci & 3 & 1,2 \\
\hline Kemal Tanca & 3 & 1,2 \\
\hline Kiğılı & 3 & 1,2 \\
\hline Damat & 3 & 1,2 \\
\hline Derimod & 2 &, 8 \\
\hline Defacto & 2 &, 8 \\
\hline Penti & 1 &, 4 \\
\hline Total & 250 & 100 \\
\hline
\end{tabular}

Table 12 shows us the rates of awareness of Turkish brands in Turkish clothing industry as Koton with 25.6\%, Mavi with 14\% and Journey with $6.4 \%$

Table 13. Perception of Turkish brands

(Tablo 13. Türk marka algısı)

\begin{tabular}{|l|r|r|r|r|r|}
\hline Explanation & $\mathrm{N}$ & Min & Max & Mean & SD \\
\hline $\begin{array}{l}\text { Preparing products to Islamic rules by } \\
\text { Turkish brands }\end{array}$ & 110 & 2 & 5 & 4,57 &, 656 \\
\hline Trust in Turkish brands & 110 & 2 & 5 & 4,44 &, 583 \\
\hline Perception of quality for Turkish brands & 110 & 2 & 5 & 4,42 &, 627 \\
\hline $\begin{array}{l}\text { Appropriateness of Turkish brands to } \\
\text { participants' own culture }\end{array}$ & 110 & 2 & 5 & 4,41 &, 580 \\
\hline Sympathy for Turkish brands & 110 & 2 & 5 & 4,36 &, 554 \\
\hline Modern style of Turkish brands & 110 & 2 & 5 & 4,35 &, 583 \\
\hline Innovation followed by Turkish brands & 110 & 2 & 5 & 4,18 &, 837 \\
\hline $\begin{array}{l}\text { Preferred Turkish brands to foreign } \\
\text { brands }\end{array}$ & 110 & 2 & 5 & 4,11 &, 738 \\
\hline
\end{tabular}

$\mathrm{N}$ : number, Min: minimum, Max: maximum, SD: standard deviation

The highest mean score related to the variables of perception for advertisements reported by the participants is seen to be "preparing products to Islamic rules by Turkish brands" as mean= 4.57, followed by "trust in Turkish brands" as mean= 4.44 and "perception of quality for Turkish brands" as mean= 4.42 . 


\section{CONCLUSION AND RECOMENDATIONS (SONUÇ VE ÖNERILER)}

As Turkish brands are successively trying to hold an important place in global brandets, they have faced a new mass of consumers in Turkey. Due to the conflicts and unrest in different countries in the Middle East, Turkey has started to receive migrations from the countries in this region. The refugees from these countries lead to an increase in domestic brandets, specially in the consumption of staple products. Companies have already formed an awareness of their products among their own citizens and consolidated the images of their products. However, the refugees newly coming from other countries meet these companies for the first time, and the awareness of these brands has just started to be formed.

As a result of the questions asked to determine why the participants choose Turkish brands, "preparing products to Islamic rules by Turkish brands", "appropriate price" and "giving importance to hygiene" are seen as impotant factors with $36.5 \%, 24.5 \%$ and $21.9 \%$, respectively. Given that all participants are Muslims and refugees living in difficult conditions in Turkey, these findings should be evaluated as normal. They choose similar brands to those with their cultural specialities and appropriate for their cultural identity. For Islamic refugees in Turkey, staple consumer products, especially food products are important to be produced according to Islamic rules.

It was seen that the participants are aware of brands related to basic consumer products such as food, clothing and GSM operators and spend more for these products. Because they have little or no opportunities to work in Turkey, or make their living with the support of Turkish Government and the United Nations, the participants have restricted their expenditures for luxurious consumer products.

In the study, a positive approach to Turkish brands is seen to be formed. The participants reported to choose Turkish brands rather than foreign ones (48.3\%), to find Turkish brands as quality products (44\%), to trust in Turkish brands (45\%) and to have sympathy for Turkish brands (54\%). As well as their domestic achievements, Turkish brands are becoming more successful in international brandets and performing more and more exports across the world. Advertisements, experiences related to brands and the environments individuals live in cause the participants to be aware of these brands.

Brands in the sector should also take these over-1-million new consumers into account. The expectations of this new group of consumers with different consuming habits and choices should be investigated. Brands should know about their preferences without neglecting the consumption of these consumers. In future studies, such issues as the expectations, wishes, dissatisfactions and satisfactions of this new group of consumers may be enlightened. Their brand habits, dependency and trends for consumption may be investigated.

\section{REFERENCES (KAYNAKLAR)}

- Aaker, D., (1991). Managing Brand Equity. Capitalizing on The Value of a Brand Name, Free Press, New York.

- Aaker, D.A., (1995). Strategic Brandet Management, John Wıley\&Sons Inc, New York.

- Aktuğlu, I.K., (2004). Marka Yönetimi, İletişim Yayınları, İstanbul.

- Ar, A., (2007). Marka ve Marka Stratejileri, Nobel Yayın Dağıtım, Ankara.

- Babür, T.N., (2010). Illetişim Temelli Marka Yönetimi, Beta Yayım Dağıtım, İstanbul. 
- Bylthe, J., (2001). Pazarlama ilkeleri (Çev. Yavuz Odabaşı), Bilim Teknik Yayın Evi, İstanbul.

- Elden, M., (2009). Reklam ve Reklamcılık, Say Yayınları, İstanbul.

- Hung, C., (2005). The Effect of Brand Image on Public Relations Perceptions and Customer Loyalty. International Journal of Management; 25(2), 237-246.

- Keller, K.L., (1993). Conceptualizing, Measuring, and Managing Customer-Based Brand Equity, Journal of Brandeting, Vol: 57.

- Knapp, E.D., (2000). Marka Aklı. Çev: Azra Tuna Akartuna, Mediacat Yayınları, İstanbul.

- Kotler, P. and Gary, A., (2004). Principles of Brandeting, Pearson-Prentice Hall Education International. New Jersey.

- Mucuk, İ., (1997). Pazarlama İlkeleri, Türkmen Kitabevi, İstanbul.

- Odabası, y. ve Mine, O., (2004). Pazarlama İletisimi Yönetimi,

- Mediacat Yayınları, İstanbul.

- Perry, A. and Wisnom III, D., (2004). Markaların DNA'si Essiz ve Dayanıklı Markaların Yaratmanın Kuralları, çev. Zeynep Yılmaz, MediaCat Kitapları, İstanbul.

- Pira, A., Kocabaş, F. ve Yeniçeri, M., (2005). Küresel Pazarda Marka Yönetimi ve Halkla İlişkiler, Dönence Basım ve Yayın Hizmetleri, İstanbul.

- Tek, Ö.B., (1997). Pazarlama İlkeleri, Global Yönetimsel Yaklaşım Türkiye Uygulamaları, Beta Yayınları, İstanbul.

- Tosun, N.B., (2010). İletişim Temelli Marka Yönetimi, Beta Yayınları, İstanbul.

- Tuna, M. ve Tuna, A.A., (2007). Kurumsal Kimlik Yönetimi, Beta Yayınları, Ankara.

- Uztuğ, F., (2002). Markan Kadar Konuş, Mediacat Yayınları, İstanbul. 